\title{
Management of Gogo Rice Production in Realizing the Commercialization of Marginal Land Farming Households in Yogyakarta
}

\author{
Wulandari Dwi Etika Rini ${ }^{1,2^{*}}$, Endang Siti Rahayu ${ }^{3}$, Mohamad Harisudin ${ }^{3}$, Supriyadi Supriyadi ${ }^{4}$ \\ ${ }^{1}$ Doctoral Program of Agriculture Science, Universitas Sebelas Maret, Kentingan, Surakarta 57126, Indonesia \\ ${ }^{2}$ Department of Agribusiness, Universitas Pembangunan Nasional "Veteran” Yogyakarta, Condongcatur, Depok, Sleman, \\ Yogyakarta 55283, Indonesia \\ ${ }^{3}$ Department of Agribusiness, Universitas Sebelas Maret, Kentingan, Kentingan, Surakarta 57126, Indonesia \\ ${ }^{4}$ Department of Agrotechnology, Universitas Sebelas Maret. Kentingan, Surakarta 57126, Indonesia
}

Corresponding Author Email: wulandari.dwi@upnyk.ac.id

https://doi.org/10.18280/ijsdp.160217

Received: 23 January 2021

Accepted: 5 April 2021

\section{Keywords:}

carrying capacity, commercialization, marginal land, marketable surplus, subsistence

\begin{abstract}
The land is an important factor for people whose lives depend on the agricultural sector. The need for land for various uses has resulted in decreasing agricultural land which could have implications for decreasing food production. Alternative options which are expected to increase the potential for food production are the utilization of marginal land. Farmers with marginal land need to manage their production to meet household needs. So it is important to examine the marketable surplus, the level of commercialization, and the carrying capacity of marginal land. The research area was taken by purposive sampling method in Gunungkidul Yogyakarta. The samples taken were upland rice farmer households with the simple random sampling method. The marketable surplus analysis uses a marketable surplus formula, then the percentage is used to determine the level of farm commercialization. The carrying capacity analysis is carried out using the carrying capacity formula. The results showed that farmer households manage rice production by allocating an average of $59.1 \%$ for marketed and $40.9 \%$ for household consumption. The allocation of marketable surplus is greater than for household consumption, this shows that gogo rice farming households are towards commercially. The marginal land carrying capacity of 0.641 indicates that the land cannot be developed in an expansive and exploratory manner. The implication is in increasing upland rice production on marginal land, namely by an intensification of farming.
\end{abstract}

\section{INTRODUCTION}

Agricultural development is closely related to increasing farmers' income. Increasing farmers' income can be done by increasing the production of land unity or productivity. Rural communities whose main livelihoods are farmers are always vulnerable to facing challenges related to increasing productivity [1]. To build the food system of the future to be sustainable needs to be a strategy in increasing production by intensification and extensification of agriculture with all risks and opportunities [2]. Extensification is an effort implemented to increase production by expanding or increasing the production factor used. The land expansion can be directed at irrigation fields, rainfed land, and untapped dry land for agriculture [3].

In reality, most agricultural activities in Indonesia are attempted by farmers as family farms with narrow land ownership of less than 0.5 ha. Agricultural land as a place of training for farmers is increasingly in decline. The decline in the land area due to the increasing population pressure on agricultural land. The main problem related to rice production in Indonesia is the reduction in paddy fields due to land conversion for non-agricultural purposes [4]. Land subsidence and population density are determinants of per capita land development [5]. Agricultural land used to produce food is converted to other uses. The narrow land area phenomenon indicates converting agricultural land into non-agricultural land [6]. If this is allowed, there will be an imbalance of the population working as farmers. As a result, the population pressure on agricultural land will increase, or in other words, the area can no longer meet its inhabitants' food needs. This will encourage the expansion of agricultural land using relatively less fertile land. One of the alternatives that can increase production potential is marginal land use. Marginalized land can be an opportunity to improve the surrounding community's socio-economic conditions by enhancing the image of the land while maintaining environmental conditions [7]. Marginal or sub-optimal land has the potential for agricultural development, such as food crops, plantation crops, and industrial plant forests [8].

In household farming with limited land conditions, farmers must manage their farms' production to fulfill household needs by selling their excess production. The excess production will be sold, which is a marketable surplus. The marketable surplus is the quantity or amount of rice production marketed by farmers [9]. Farmers who produce products by meeting the needs of family consumption are referred to as subsistence farmers. Agricultural production can affect different farming types, namely subsistence and commercial farming [10]. Most smallholder farmers focus on a subsistence production level 
that they produce only for self-consumption [11]. The subsistence level is a classification based on the pattern of farming. The farming pattern is intended as a level of agricultural management determined by various measures, namely the degree of commercialization of agricultural production. With that size can be seen as the static, transitional, and dynamic level of a farm. In agricultural management, the farmers' socio-economic conditions will provide the basis for determining the type of farming [12]. Changing a subsistenceoriented production system to a commercially oriented one is a way to increase small farmers [13].

The level of commercialization of farmers depends on the condition of the farmland. Agricultural land resources are essential in supporting agricultural production cultivated by farmers [14]. If the land used for farming supports means it can provide products that can meet households' needs, farmers will be oriented for commercial purposes. In the agricultural sector, the carrying capacity ratio compares available land and the number of farmers. The carrying capacity analysis can provide the necessary information in assessing the level of land capability in supporting all human activities in the region. The land carrying capacity of an area reflects the relationship between human economic and social activities and the surrounding natural environment [15]. Land capability is very important for sustainable land use [16]. Environmental potential needs to be maintained by carrying out maintenance to guarantee environmentally friendly practices to achieve sustainable resource use [17]. The limiting factors of the land capabilities are uneven topography, parent material dominance, nutrient content, small organic matter, low gas levels, too short, or too high $\mathrm{pH}$. Optimally unused land that is sub-optimal still has the potential to be developed. Suboptimal land or marginal land includes dry land, tides, and swamps.

In Yogyakarta, the most extensive dry land is located in Gunungkidul Regency, an area with high rainfall but rarely rain, tropical climate area, with the topography of the area dominated by the karst hill area. The main challenge in the karst area condition is to empower and help small farmers by providing sustainable land management knowledge in their farming activities. It maintains the livelihoods of farmers who tend to prioritize profit rather than safeguarding the environment [18]. The area of Gunungkidul Regency is $90 \%$ dry land and very dependent on rainfall. The irrigated land is relatively narrow, and most of the land is rainfed. In rainfed land, farmer households meet their food needs by cultivating upland rice. Upland rice farming for farmer households is a job that can generate income to meet family needs. The yield of upland rice will be used to meet food needs, and the rest will be sold to meet the living needs of other farming households. Therefore, farmers need to manage upland rice production for both food and different living needs. With rainfed land, agriculture is heavily dependent on rainfall forecasts and runoff [19].

The most considerable contribution to rice production in Gunungkidul Regency comes from marginal land. For gogo rice farmers with constraints on limited land conditions, the rice production produced will be processed into unhulled rice. The gogo rice production will meet consumption needs, and the excess upland rice will be sold. With limited land area and land quality, farmer households in Gunungkidul Regency in certain regions are still planting gogo rice twice the planting season in one year. The habit of farmers is that rice production is entirely to meet household needs, so they are referred to as subsistence farmers. With food diversity, farmers have experienced changes in their farming management by selling excess production after meeting family consumption needs. This will affect the farming patterns carried out by farmers and the level of commercialization of the farmer's household. Therefore it is necessary to have land carrying capacity and land suitability, which are places for farmers to do their business.

For farmer households, the land is an important resource in increasing rice production. So that if production increases, farmers will be commercially oriented in their farming activities. To increase household income, farmers must manage their business by allocating resources in the production process and allocating production for food and other living needs. In this regard, it is necessary to conduct research to determine marketable surpluses, the level of commercialization of farming, and the carrying capacity of agricultural land considering that gogo rice farmers' marginal land use is still limited in quality and quantity. This is the novelty of this research because based on the literature search the previous research has never studied marketable surplus, level of commercialization, and carrying capacity of gogo rice commodities on marginal land.

\section{METHODOLOGY}

The research uses a descriptive quantitative method. The quantitative method according to [20] is a research method used to examine a specific population or sample, data collection using research instruments, data analysis is quantitative in nature. The quantitative descriptive method in this research is used because this study using a specific sample, collecting data using research instruments of observation, interviews, or questionnaires with quantitative data. This quantitative approach is used to obtain quantitative data needed in this study for the purpose of analyzing the marketable surplus, the level of commercialization of farming, and the carrying capacity of marginal land in gogo rice farmer households. The research area's determination was carried out using a purposive sampling method, which was determined in Gunungkidul Regency, Yogyakarta Special Region, considering that there were gogo rice farmer households who planted gogo rice twice a year on marginal lands. The method of taking gogo rice farmer household samples using a simple random sampling method. This method is used with consideration of a homogeneous population so that sampling can be carried out randomly, with the criteria of gogo rice farmer households who plant gogo rice twice a year. The number of upland rice farmer household populations that meet the criteria is 1,550 households. According to [21] in descriptive research, the minimum sample is $10 \%$ of the population. So that in this research a sample of 178 gogo rice farmer households was determined. Data collection techniques by interviewing, recording, and observation.

The marketable surplus is the number of products sold by farmers regardless of their needs for family consumption, agricultural markets, and other family needs [22]. To analyze the marketable surplus related to the production of gogo rice produced in marginal land conditions used the following formula:

$$
Q=M+C
$$


Information:

$Q=$ quantity of rice produced

$M=$ Marketable surplus

$C=$ quantity of rice consumed

If the production is greater than the family's consumption, then there will be a surplus of rice. The amount of surplus rice that will be sold is called the marketable surplus. From the calculation of marketable surplus will be seen, the commercialization of gogo rice farming is included in the criteria static, transition, dynamic, and farming in subsistence or commercial state.

In the agricultural sector, the carrying capacity ratio $(C C R)$ compares available land and the number of farmers. Analysis of the land's carrying capacity is used to calculate the optimal environmental ability to provide a good life and meet the quality requirements for community life in the area [23]. The benefit of carrying capacity of the land is that it can be seen that the land ability to support the basic needs of the population, the potential for development, and see environmental sustainability in land use accordance with its power. To analyze the carrying capacity of the land, namely with the formula:

$$
C C R=\frac{\mathrm{A} \times \mathrm{r}}{\mathrm{H} \times \mathrm{h} \times \mathrm{F}}
$$

Information:

$C C R=$ Carrying Capacity Ratio

$\mathrm{A}=$ Total number of areas that can be used for agricultural activities (ha)

$\mathrm{r}=$ Harvest frequency per ha per year

$\mathrm{H}=$ Number of family members (people)

$\mathrm{h}=$ Percentage of the population living $(\%)$

$\mathrm{F}=$ Average farmland size owned (ha)

If $C C R>1$, based on land quantity, can still support human needs and can receive additional population. Development in the area is still possible to be expansive and exploratory land. If $C C R<1$, that means based on the amount of land that exists, then it is no longer possible to do expansions and exploratory development in the area. If $C C R=1$, that means based on the amount of land, this area still balances land capability and population.

\section{RESULT AND DISCUSSION}

\subsection{Marketable surplus}

Farm management needs to pay attention to the characteristics of the land used. Based on the water condition, land types are divided into irrigated rice fields, rainfed rice fields, dry land, and swamps. The farming success of this type of land will be very different depending on the plants' technical and economic feasibility of the plants' response to the cultivated land's characteristics. Farm management in Suboptimal land will be an alternative for food procurement in the future, and rainfed land is the second rice barn after paddy fields. Rainfed lowland rice fields are generally infertile, often experiencing drought, and farmers do not have enough capital, so this agro-ecosystem is also called a resource-poor area [24]. This type of land only produces in the rainy season. The agricultural land owned by Gunungkidul Regency is mostly rainfed dry land, which depends on climate cycles, especially rainfall. In connection with the marginal land conditions, gogo rice farmers do twice the planting season even though it is full of crop failure risk in the second planting season. This is to meet household consumption needs from gogo rice production. After the family's consumption needs are met, farmers will sell the excess production. If production is greater than household consumption, rice will be a surplus. The rice surplus will be sold to meet the needs of other households.

Gogo rice production will be allocated by upland rice farmer households to meet their household consumption needs and the excess will be sold to meet other household needs. The average upland rice production, upland rice consumption, and marketable upland rice surplus, households of upland rice farmers can be seen in Table 1 .

Table 1. Average production, consumption, and marketable surplus by gogo rice farmers

\begin{tabular}{cccc}
\hline No. & Description & $\begin{array}{c}\text { Amount } \\
\text { (kg/year) }\end{array}$ & $\begin{array}{c}\text { Percentage } \\
(\%)\end{array}$ \\
\hline 1. & $\begin{array}{c}\text { Production of gogo } \\
\text { rice }\end{array}$ & $1,642.107$ & 100.0 \\
2. & $\begin{array}{c}\text { Consumption of gogo } \\
\text { rice }\end{array}$ & 671.812 & 40.9 \\
3. & Marketable surplus & 970.295 & 59.1 \\
\hline Source: Primary data analysis & &
\end{tabular}

Based on Table 1, it can be seen that after the consumption needs of farmer households are met in the amount of 671.812 $\mathrm{kg}$ or $40.9 \%$, then excess production of $970.295 \mathrm{~kg}$ will be sold to meet the needs of other households or by $59.1 \%$. This shows that the production allocated for farmers' household consumption is smaller than those sold by farmers. The farmers' decision to allocate upland rice production for household consumption and what farmers sell is a habit that has been practiced by farmers. Farmers will sell the remaining products after the need for household consumption is met. This is different things with research conducted by [25] these subsistence-oriented households must produce more products to satisfy household consumption needs and allocate smaller products for sale, resulting in a smaller marketable surplus for each product. Research on lowland rice conducted by [26], showing marketable rice surplus in rice farming families in Sukoharjo is $6,057 \mathrm{~kg}(73.92 \%)$ while the remaining $2,137 \mathrm{~kg}$ $(26.08 \%)$ is used for farmer consumption. The results of the marketable gogo rice surplus research in the Gunungkidul Regency can be shown in Figure 1.

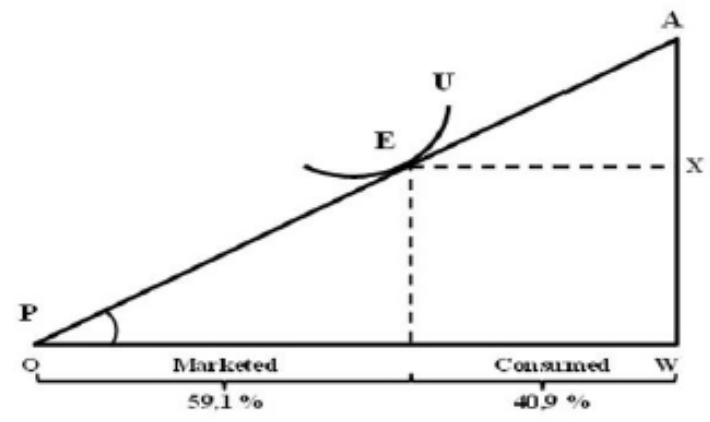

Figure 1. Allocation of gogo rice production for consumption and marketable surplus in gogo rice farmer's household

Based on Figure 1, suppose that upland rice farmers' income is only generated from upland rice production of $1,642.107 \mathrm{~kg}$ 
(OW). In that case, the farmer will allocate production for household consumption, and the rest will be sold by maximizing economic welfare or the satisfaction of family members (U). It is assumed that satisfaction (U) comes from the consumption of upland rice and consumption of goods other than upland rice $(\mathrm{X})$. If $\mathrm{P}$ is the price, upland rice farmers can follow the PA route by exchanging rice for $970.295 \mathrm{~kg}$ or $59.1 \%$ to get other goods in $\mathrm{X}$, while the products consumed are $671.812 \mathrm{~kg}$ or $40.9 \%$. Then (E) is a condition in which the farmer household reaches a balance between production that is sold for other needs and production that is used for household consumption itself. Determination of the number of products consumed and sold by taking into account household needs, product selling price, land area, and land productivity. Farm household needs include food and non-food needs. The condition of the land area of farmers, including small farmers, with an average land area of less than 0.5 ha.

\subsection{Commercialization}

From the calculation of the marketable surplus of $59.1 \%$, it can be seen that the gogo rice farming pattern is included in the transition criteria towards dynamic. Based on the criteria, upland rice farmer households are included in semicommercial farmers namely from subsistence towards commercial [27]. This can be seen from the percentage of gogo rice production sales, which is greater than $50 \%$. This is not in line with [28] opinion which states that subsistence farming is a condition that is still prevalent among small farmers. The results show that the farmers were no longer subsistence, even though they were small farmers. Farmers will sell their rice production after fulfilling their consumption needs. Farmers' households do not only depend on gogo rice to meet their consumption needs, but have diversified their consumption. Because farmers diversify their consumption, there is a surplus in rice production that can be sold by farmers to meet other household needs. This can be shown in Figure 2.

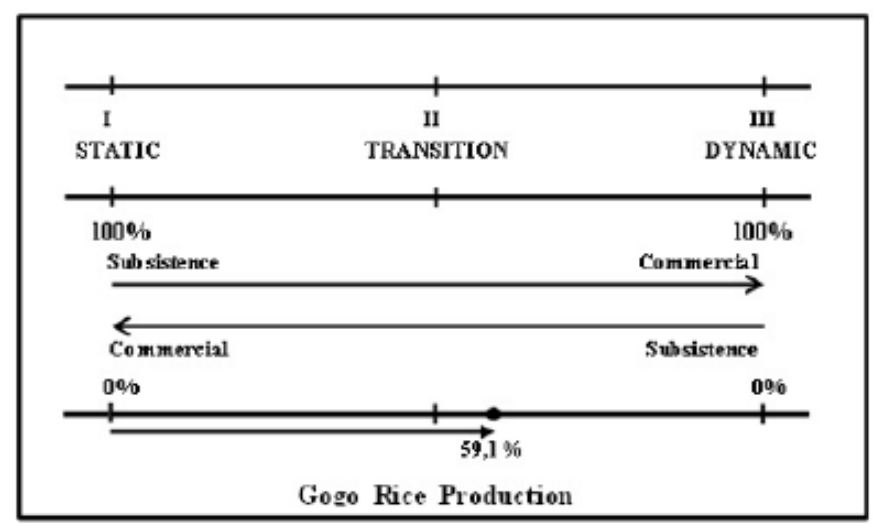

Figure 2. Gogo rice farmer household business commercialization rate

Figure 2 shows that of the total rice production produced by farmers, $40.9 \%$ is allocated by farmers for household consumption needs. The excess production of $59.1 \%$ will be sold by farmers whose sales proceeds can be used to meet other needs. Other household needs include needs for clothing, health, education, communication, transportation, and recreation. The level of commercialization of upland rice farming is in a pattern from transition towards dynamic. From the upland rice farming, which shows that the more product allocation is sold, it means that the management of farm household production is in a transition state towards dynamic. This shows that farmers are no longer purely subsistence. Characteristics of subsistence farmer households include farmer household decisions for consumption and production decisions [29]. Consumption decisions, namely to meet household food needs. Poduction decisions, namely to allocate resources owned by farmers. Farm management is very important in resource management in the production process and product allocation for household consumption needs and for marketing.

\subsection{Carrying capacity}

The essential resource in the production process is the land. Land use decisions for individual farmers require information on land resources in assessing benefits and impacts on land use [30]. Therefore, it is necessary to analyze the carrying capacity of the land, because gogo rice farmers' land is classified as marginal land. Land carrying capacity is for seeing the ability of the land to support life. The carrying capacity of agricultural land depends on the percentage of land area used for agriculture and the amount of agricultural products unitary area and time. In the agricultural sector, carrying capacity is the ratio between available land and the number of farmers

So thet it is necessary to analyze the area of land used by farmer households, the potentially available land, and its use for agricultural activities. The ecological carrying capacity of a product indicates the area of land necessary to support production [31]. It is essential to know how much land is needed per household, the potentially available land, and its use for agricultural activities. To analyze the carrying capacity of land using the data calculation in Table 2.

Table 2. Data on carrying capacity of rainfed households of gogo rice farmers

\begin{tabular}{ccc}
\hline Description & Value & Unit \\
\hline The total area of gogo rice farming (A) & 30.895 & ha \\
Frequency of harvest (r) & 2 & Times/year \\
Number of farm family members (H) & 556 & People \\
Family members who live (h) & 100 & $\%$ \\
Average land area (f) & 0.1735 & ha \\
\hline Source: Primary data analysis & &
\end{tabular}

Analysis of the carrying capacity of gogo rice farmers is:

$$
C C R=\frac{30.895 \times 2}{556 \times 100 \% \times 0.1735}=0.641
$$

The analysis results show a $C C R$ value of 0.641 , and it shows that based on the amount of land available, in that area, it is no longer possible to develop expansive and explorative land. This results in line with research by [32] that the overall carrying capacity of food crops is 0.414 . This means that agricultural land is not yet capable of implementing food selfsufficiency and providing sufficient food. Likewise, with the research of [33], which states that the carrying capacity of the watershed agricultural land as a whole is still low, this shows that the watershed has not been able to self-sufficient in food and meet food needs a decent life for its resident.

The results of the analysis of the land's carrying capacity show that for rainfed land in the study area shows that for gogo rice farmers households, the $C C R$ value $<1$. The $C C R$ value $<$ 1 means that it is no longer possible to develop expansive 
development and explorative based on the amount of land available. The land is not able to support the living needs of farmer households. Allocation of land use so that land is optimal about competition for land use with multiple purposes requires land-use planning [34]. This occurs due to limited land owned by farmers and marginal land conditions. The marginal land owned by farmers is dry land, where water availability is very limited. Adequacy of water only depends on the rainfall. The quality of water contained in the soil will affect the quality of life, social conditions, and economic growth of an area [35]. The quality of water in marginal land farmers will affect the farming patterns on their land. Upland rice cultivation with two growing seasons requires knowledge in predicting climate. In the second planting season, the need for water was insufficient, so farmers' efforts were needed to optimize their land due to limited water availability. Increasing upland rice production that only relies on rainfall can be done by anticipating climatic conditions. Climatic conditions are difficult to predict, so it is hoped that the planting time in the second planting season can be done earlier. Farmers must be assisted by information in knowing climate predictions in determining planting time. A land condition that is no longer possible for expansion and exploration, the thing that needs to be done is an intensification of farming by adjusting climatic conditions. The level of household survival of gogo rice farmers with limited land conditions that cannot be developed expansively and exploratively to meet their daily needs is supported by other income-generating jobs. Farmer households on marginal land, apart from working as a farmer, have a side job. So that the side income factor, the allocation of labor is an important factor to be studied but has not been included in this study. Other factors that have not been included in the analysis will be conducted by incorporating these factors in further research.

\section{CONCLUSIONS}

Marketable surplus gogo rice of 59.1\% indicates that upland rice farming management is included in the transition criteria towards dynamic. The level of commercialization of farm households is semi- commercial from subsistence towards commercial by looking at the percentage of gogo rice production sales, which is greater than $50 \%$. Farm households allocate their production to meet their farm household's food consumption needs first, and then the excess production will be sold to meet other living needs. The carrying capacity value of land is 0.641 , which means $<1$. It shows that based on the amount of land available in the area, it is no longer possible to develop expansive and exploratory land. Farmers' land is marginal land, including dry land, which is highly dependent on rainfall, has not been able to meet the needs of farmer households properly.

The level of commercialization of farmer households towards commercial but the carrying capacity of the land has not been able to fulfill a decent living, due to limited and marginal land conditions. Farming management is needed, so that farmer households are more commercial in their farming so that they can increase farm household income. In addition government intervention is through agricultural extension agents to provide information and guidance to upland rice farmers about climate change so that farmers can optimize the potential of existing resources because they do not allow land expansion for farmers. Increasing the production of upland rainfed rice, which relies on rainfall, can be done by intensification of farming, and anticipating unpredictable climatic conditions. So there needs to be assistance for farmers to determine planting time by determining cropping calendar.

\section{ACKNOWLEDGMENT}

The research is supported by Directorate of Research and Community Service, the Directorate General of Research and Development Strengthening, the Ministry of Research and Technology.

\section{REFERENCES}

[1] Haruna, Y., Gambo, A., Oluwatuyi, A., Zakari, A. (2020) Climate change adaptation practices and rice farmers' level of living in northwest, Nigeria. Journal of Agricultural Extension, 24(3): 49-60. https://doi.org/10.4314/jae.v24i3.5

[2] Van Grinsven, H.J.M., Erisman, J.W., De Vries, W., Westhoek, H. (2015). Potential of extensification of European agriculture for a more sustainable food system, focusing on nitrogen. Environmental Research Letters, 10(2). https://doi.org/10.1088/1748-9326/10/2/025002

[3] Yuniarsih, E.T., Taufiq, M. (2020). Analysis economic efficiency use of production factors corn farming on marginal land in south Sulawesi. IOP Conference Series: Earth and Environmental Science, 484(1). https://doi.org/10.1088/1755-1315/484/1/012141

[4] Mucharam, I., Rustiadi, E., Fauzi, A., Harianto. (2020). Assessment of rice farming sustainability: Evidence from Indonesia provincial data. International Journal of Sustainable Development and Planning, 15(8): 13231332. https://doi.org/10.18280/ijsdp.150819

[5] Shi, Y., Shi, S., Wang, H. (2019). Reconsideration of the methodology for estimation of land population carrying capacity in shanghai metropolis. Science of the Total Environment, 652: 367-381. https://doi.org/10.1016/j.scitotenv.2018.10.210

[6] Singkawijaya, F. (2019). Agricultural conversion phenomenon to non-agricultural land in Tasikmalaya city. International Journal of Innovation Creativity and Change, 9(1): 157-166.

[7] Cervelli, E., Scotto di Perta, S., Pindozzi, S. (2020). Energy crops in marginal areas: scenario-based assessment through ecosystem services, as support to sustainable development. Ecological Indicators. 113: 106180. https://doi.org/10.1016/j.ecolind.2020.106180

[8] Suharta, N. (2010). Karakteristik Dan Permasalahan Tanah Marginal Dari Batuan Sedimen Masam Di Kalimantan. Jurnal Litbang Pertanian, 29(4): 139-146.

[9] Mustaman, H., Sukiyono, K., Nusril. (2019). Rice marketable surplus, marketed supply and its determinant factors in Mukomuko district. Journal of Agri SocioEconomics $\quad$ Business, 1(1): 1-14. https://doi.org/10.31186/jaseb.1.1.1-14

[10] Muthini, D., Nzuma, J., Qaim, M. (2020). Subsistence production, markets, and dietary diversity in the kenyan small farm sector. Food Policy, 97: 101956. https://doi.org/10.1016/j.foodpol.2020.101956

[11] Abdullah, Rabbi, F., Ahamad, R., Ali, S., chandio, A., Ahmad, W., Ilyas, A. (2019). Determinants of 
commercialization and its impact on the welfare of smallholder rice farmers by using Heckman'S two-stage approach. Journal of the Saudi Society of Agricultural Sciences, $\quad 18(2)$ : https://doi.org/10.1016/j.jssas.2017.06.001

224-233

[12] O'Rourke, E., Kramm, N., Chisholm, N. (2012). The influence of farming styles on the management of the Iveragh uplands, southwest Ireland. Land use Policy, 29(4): 805-816. https://doi.org/10.1016/j.landusepol.2011.12.008

[13] Aman, T., Adam, B., Lemma, Z. (2014). Determinants of smallholder commercialization of horticultural crops in Gemechis district, West Hararghe Zone, Ethiopia. African Journal of Agricultural Research, 9(3): 310-319. https://doi.org/10.5897/ajar2013.6935

[14] Chai, J., Wang, Z., Yang, J., Zhang, L. (2018). Analysis for spatial-temporal changes of grain production and farmland resource: Evidence from Hubei province, central China. Journal of Cleaner Production. https://doi.org/10.1016/j.jclepro.2018.10.008

[15] Wu, X., Hu, F. (2019). Analysis of ecological carrying capacity using a fuzzy comprehensive evaluation method. Ecological Indicator, 113: 106243. https://doi.org/10.1016/j.ecolind.2020.106243

[16] Atalay, I. (2016). A new approach to the land capability classification: case study of Turkey. Procedia Environmental Sciences, 32: 264-274. https://doi.org/10.1016/j.proenv.2016.03.031

[17] Obina. L. (2019). Soil conservation and water resources management techniques used by small scale rice farmers in Ebonyi State, Nigeria. Journal of Agricultural Extension, 23(4): 58-64. https://doi.org/10.4314/jae.v23i4.7 Obinna

[18] Oliver, D.M., Zheng, Y., Naylor, L.A., Murtagh, M., Waldron, S., Peng, T. (2020). How does Smallholder farming practice and environmental awareness vary across village communities in the karst terrain of southwest China? Agriculture, Ecosystems, and Environment, 288 : 106715 https://doi.org/10.1016/j.agee.2019.106715

[19] Murray-Tortarolo, G.N., Jaramillo, V.J., Larsen, J. (2018). Food security and climate Change: The case of rainfed maize production in Mexico. Agricultural and Forest Meteorology, 253-254: 124-131. https://doi.org/10.1016/j.agrformet.2018.02.011

[20] Sugiyono. (2017). Metode Penelitian Kuantitatif, Kualitatif. Alfabeta. Bandung, Indonesia.

[21] Gay, L.R., Diehl, P.L. (1996). Research Methods for Business and Management. International Edition. Prentice Hall. New Jersey.

[22] Kumar, V., Dwivedi, S., Narain, S., Rawat, S.K., Chauhan. B. (2015). Assessment of marketable and marketed surplus of rice in relation to farm size. AgroEconomist, 2(2): 13-16. https://doi.org/10.5958/23948159.2015.00013.4

[23] Achmad Tjahja, N., Prayitno, G., Wardana, N.W.S. (2019). Analysis of land carrying capacity for the development of leading commodities in Kulon Progo regency, Indonesia. International Journal of GEOMATE. 16(53): https://doi.org/10.21660/2019.53.37276

[24] Pirngadi, K., Makarim, A.K. (2006). Peningkatan Produktivitas Padi pada Lahan Sawah Tadah Hujan melalui Pengelolaan Tanaman Terpadu. Penelitian Pertanian Tanaman Pangan, 25(2): 116-123.

[25] Fredriksson, L., Bailey, A., Davidova, S., Gorton, M., Traikova, D. (2017). The Commercialisation of subsistence farms: Evidence from the New Member States of the EU. Land Use Policy, 60: 37-47. https://doi.org/10.1016/j.landusepol.2016.10.009

[26] Afifah, A.N., Suprapti S., Agusono. (2016). Analisis Faktor-Faktor yang Mempengaruhi Marketable Surplus Beras Pada Keluarga Petani Padi Di Kabupaten Sukoharjo. Agrista, 4(3): 472-481.

[27] Hernanto, F. (1993). Ilmu Usahatani. 309 hlm. Penebar Swadaya. Jakarta. Indonesia.

[28] Ingabire, C., Mshenga, M.P., Langat, K., Bigler, C., Musoni, A., Butare, L., Birachi, E. (2017). Towards commercial agriculture in rwanda: understanding the determinants of market participation among smallholder bean farmers. African Journal of Food, Agriculture, Nutrition, and Development, 17(4): 12492-12508. https://doi.org/10.18697/ajfand.80.16825

[29] Alexandri, C., Luca, L., Kevorchian, C. (2015). Subsistence economy and food security - the case of rural households from Romania. Procedia Economics and Finance, 22: 672-680. https://doi.org/10.1016/s22125671(15)00282-8

[30] Lilburne, L., Eger, A., Mudge, P., Ausseil, A.G., Stevenson, B., Herzig, A., Beare, M. (2020). The land resource circle: Supporting land-use decision making with an ecosystem-service-based framework of soil functions. Geoderma, 363: 114134. https://doi.org/10.1016/j.geoderma.2019.114134

[31] Cuadra, M., Björklund, J. (2007). Assessment of economic and ecological carrying capacity of agricultural crops in Nicaragua. Ecological Indicators, 7: 133-149. https://doi.org/10.1016/j.ecolind. 2005.11.003

[32] Talumingan, C., Jocom, S. (2017). Kajian Daya Dukung Lahan Pertanian Dalam Menunjang Swasembada Pangan Di Kabupaten Minahasa Selatan, Agri-SosioEkonomi, 13(1): $11-24$ https://doi.org/10.35791/agrsosek.13.1.2017.14881

[33] Mubarokah, N., Rachman, L.M., Tarigan, S.D. (2020). Analisis Daya Dukung Lahan pertanian Tanaman Pangan Daerah Aliran Sungai Cibaliung, Provinsi Banten. Jurnal Ilmu Pertanian Indonesia, 25(1): 73-80. https://doi.org/10.18343/jipi.25.1.73

[34] Ahmadi Mirghaed, F., Mohammadzadeh, M., Salmanmahiny, A., Mirkarimi, S.H. (2020). Decision scenarios using ecosystem services for land allocation optimization across Gharehsoo watershed in northern Iran. Ecological Indicators, 117: 106645. https://doi.org/10.1016/j.ecolind.2020.106645

[35] Ding, D., Zhang, L., Liu, J., Chen, F., Si, X. (2020). Design and implementation of a comprehensive evaluation model for shallow groundwater based on matter element extension. International Journal of Design and Nature and Ecodynamics, 15(5): 685-689. https://doi.org/10.18280/ijdne.150510 